\title{
The Impact of Dark Triads on employee's Time Banditry Behavior: Moderating Role of Islamic Work Ethics
}

\author{
Shuja UI Islam ${ }^{1 *}$, Abdul Wahab ${ }^{2}$, Haider Ali Malik ${ }^{3}$, Erum Sana Nawab ${ }^{4}$ \\ 1, 2, 3 National University of Computer and Emerging Sciences, Islamabad, Pakistan \\ ${ }^{4}$ National Saving Centre, Islamabad, Pakistan
}

\section{Keywords \\ Dark Triad \\ Islamic Work Ethics \\ Time Banditry}

Received: 27 November 2020

Accepted: 13 January 2021

\begin{abstract}
.
Purpose: The present study scrutinizes the novel concept of time banditry in the Banking sector. The study examined the impact of dark triad personalities- Machiavellianism, Narcissism, and Psychopathy, on the Time Banditry behavior. Also, the study extends the research on Islamic work ethics (IWE), whether IWE attenuates the detrimental effect of dark triad personalities on time banditry.

Methodology: The study utilizes the survey method for data collection using questionnaire. Data was collected from 204 employees working in Islamic banks. Time-lagged data was collected at two time interval.

Findings: Results confirmed that the dark triad has a significant impact on time banditry. Moreover, the moderating effect of IWE on the relationship between Machiavellianism, Psychopathy on time banditry is significant, whereas IWE did not moderate the relationship between Narcissism and time banditry.

Significance: This is the first study that examine the impact of Dark Triad on Time Banditry and explore that whether Islamic Work Ethics attenuate this relationship in the context of Islamic banks in Pakistan.

Implications: The main theoretical implication is toextends Dark triad literature in reducing its deteriorating effect on time banditry by integrating IWE. The theoretical model tested in the study and confirm empirical evidences in literature.

Practical and Social Implications: This study prompts manager about the critical issue of time banditry and amond the dark traid personalities, which personality have more chances to indulge in such behavior. Also, managers can handle the dark triad employees by integrating IWE, to less indulge in undesirable behavior.
\end{abstract}

KAUJIE Classification: H54, M84

JEL Classification: M12, M5

\footnotetext{
*Corresponding author: Shuja Ul Islam

${ }^{\dagger}$ Email: shujaul.islam@nu.edu.pk; ORCID: https://orcid.org/0000-0001-6172-7498
} 


\section{INTRODUCTION}

Does your organization have employees who come late or sneak out before time regularly? What about the workers who use mobile phones throughout the day for non-business purposes or waste their time in the workplace? Time banditry, time theft, and cyberloafing in the workplace is a growing global challenge for managers. Time theft is a very common and costly form of ethical misconduct, which has been understudied by ethics researchers (Brock Baskin \& McKee, 2019; Henle et al., 2010). A study deduced that time theft is so common at organizations that $84 \%$ of participants reported being involved in time theft at least once in 2 months (Henle et al., 2010). Time Banditry is defined as "the propensity of employees to engage in unsanctioned, non-work related activities during work time" (Martin et al., 2010). Few studies have focused primarily on the individual and job-level antecedents (Brock et al., 2017; Brock et al., 2013; Henle et al., 2010; Martin et al., 2010). At an individual level, scholars focused on the detrimental effect of the dark triad on undesirable workplace behavior e.g. counterproductive work behavior, workplace deviance, and workplace bullying (Harms et al., 2011; Kish-Gephart et al., 2010; Daderman \& Ragnestal-Impola, 2019). Dark Triad (DT) of personality has been considered an important cluster of distinct negative personality i.e., Machiavellianism, narcissism, and psychopathy (Paulhus \& Williams, 2002). Though these are three distinct traits that callousness or disregard of others is the reason that leads to the overlap of these Dark Triads (Jones \& Paulhus, 2010). Scant studies have focused on mitigating the damaging effect of the Dark triad in the workplace via high involvement management climate and workplace spirituality (Webster \& Smith, 2019, Lata \& Chaudhary, 2020).

Workplace ethics plays a significant role in determining the employee's attitude and behavior in the workplace. Islamic work ethics have been studied as a moderator in several studies to lessen the deleterious effect of undesirable behaviors at the workplace such as abusive supervision (Hashmi et al., 2019; Islam et al., 2020; Javed et al., 2019; Khalid et al., 2018), challenge and hindrance stressors (Tufail et al., 2017), interpersonal conflict with mediating effect of psychological distress (Qayyum et al., 2018), and supervisor expediency (Fayyaz et al., 2020).

Ali (1992) indicated Islamic work ethics as an orientation towards the workplace. Job is a virtue for balancing a personal and social life. IWE is a complete code of conduct that follows the Qur'ān and Sunnah of the Prophet Muhammad (PBUH). Every Muslim will hold this notion during working on the job (Beekun \& Badawi, 2005). Previous studies indicate that IWE, or the extent to which a person follows the principles of Islamic work in his or her work, gives workers positive drives to work and act with a certain moral rightness (Murtaza et al., 2016). Khan et al. (2015) argued that IWE includes focusing on jobs and preventing the accumulation of capital utilizing unethical interventions. Yousef (2001) said IWE gave greater priority than findings to intentions. Any activity meant to hurt others but favor those who do so is treated as unlawful in Islam (Ali \& Al-Owaihan, 2008). Researchers suggest ethics are moral philosophies that help people differentiate between right and wrong (Khan et al., 2015). Syed and Ali (2010) emphasized that Muslims must follow the Islamic code of morals and surrender to Allah and His will. Following Islamic philosophies, Rice (1999. p. 
346) stated: "it is the ethics that dominates economics and not the other way around". Qur'ān says that "for all people, there are ranks according to their deeds" (Qur'ān 6:132). The theory of planned behavior proves that individuals' attitudes, beliefs, and intentions lead to their behavior, which controls the individual acts (Fishbein \& Ajzen, 1980). Based on the theory of planned behavior, the researcher argues that a person who believes in the philosophy of IWE will refrain from involving in unethical practices even in the presence of dark triads because of self-control.

These shreds of evidence suggest that employees in the different contextual settings will perform differently, whereas most of the studies have focused on the supervisor role and its impact on employee outcomes. Based on the scant literature on individual personality and its impact on negative outcomes especially from the perspective of Islamic work ethics, the study has two main objectives: 1) To identify the impact of the dark triad on time banditry and which personality will be more inclined. 2) To identify whether IWE attenuates the impact of the Dark triad on Time banditry.

The current research will contribute to the dark triad literature is threefold. Firstly, we explored the impact of the dark triad on the time banditry highlighting that which personality trait is the most detrimental. Secondly, the buffering factor can weaken the relationship between the dark triad and time banditry. Lastly, the study is conducted in the eastern context, specifically Pakistan, where the majority population's religion is Islam.

\section{LITERATURE REVIEW}

Since the last decade, researchers have found interest in exploring Counterproductive Work Behavior (CWB) in the context of Dark triads. Dark Triad (DT) has been considered an important cluster of distinct personalities i.e. Machiavellianism, narcissism, and psychopathy (Paulhus \& William, 2002). Several studies have confirmed the impact of the Dark Triad on CWBs is evident (e.g., Grijalva \& Newman, 2015; O'Boyle et al., 2012). In addition to this, scant researches studied the impact of personality on cyberloafing (Jia et al., 2013), whereas the impact of the dark triad on time banditry remains unexplored. From the IWE perspective, researchers have suggested a further emphasis on its buffering role in undesirable practices at the workplace (Khan et al., 2015).

\section{Machiavellianism and Time Banditry}

Machiavellians are individuals who have a strong manipulative tendency and to deceive for personal gains, irrespective of how these gains are achieved (Christie \& Geis, 1970). These individuals can judge and exploit the weaknesses of other individuals. They are less likely to get emotionally involved with others and do not deviate from their actions and beliefs. They also have a cynical view and assume that rather than being manipulated, it's better to manipulate others (Dahling et al., 2009; John \& Paulhus. 2009). In recent research, it was deduced that correlations between all types of CWB and Machiavellianism were notably positive, but the relationship between Machiavellianism and CWB was negative when controlled for psychopathy and narcissism. This means that the shared variance between the Dark triad can impact the extent to which Machiavellians get involved in CWB (Palmer et 
al., 2017). Machiavellianism also has a significant positive impact on the supervisor's expediency (Fayyaz et al., 2020), workplace incivility (Lata \& Chaudhary, 2020), and bullying (Daderman \& Ragnestal-Impola, 2019) in various contexts.

Research conducted by Bennett and Robinson (2000) suggests that due to Machiavellianism's deceitful characteristic, these personnels are likely to be engaged in workplace deviance. Machiavellians are focused on their self-interest, and therefore to achieve the goals, they are likely to indulge in deceptive behavior (Giammarco et al., 2013). Additionally, they are also involved in counterproductive workplace behavior relationships (Schneider \& Goffin, 2012), and undesirable behavior i.e. cyberloafing (Lowe-Calverley \& Grieve, 2017). Therefore, in our research, the following hypothesis is proposed:

H1: Machiavellianism is positively associated with Time Banditry

\section{Narcissism and Time Banditry}

People high in narcissism engage in self-enhancement behaviors like seeing themselves as a natural leader, low empathy, over-claiming, and attention-seeking attributes (Palmer et al., 2017; Paulhus \& William, 2002; Raskin \& Terry, 1988). Few researchers have shown the association of narcissism with aggression (Bushman \& Baumeister, 1998), workplace incivility (Lata \& Chaudhary, 2020), and bullying (Daderman \& Ragnestal-Impola, 2019) in various contexts. Studies confirmed that narcissistic personnel is more likely to depict negative behaviors, leading to a destructive relationship (Fayyaz et al., 2020, Campbell \& Foster, 2002). Narcissists show violence and aggression against individuals (Bushman \& Baumeister, 1998). Therefore, it can be said that narcissist individuals are more likely to engage in workplace deviance during their self-enhancement activities (Raskin \& Terry, 1988). It is confirmed in previous researches that narcissism is a prominent predictor of CWBs (O'Boyle et al., 2012).

Narcissists are self-centered, self-obsessed, and believe that they can make the best decisions for themselves i.e., a sense of entitlement. Due to this sense of entitlement, Narcissists are also involved in 'not having to play by the rules' (Lowe-Calverley \& Grieve, 2017), also based on lying (Ford et al., 1988). Narcissists' characteristics of dominance and superiority (Paulhus \& Williams, 2002) may increase their lying and deception behaviour. Moreover, their superiority and not abiding by the rules are engaged in undesirable workplace behavior (O'Boyle et al., 2012). Therefore, we hypothesized that:

H2: Narcissism is positively associated with Time Banditry Psychopathy and Time Banditry

In the last few decades, Psychopathy has been a topic of attention for researchers (Patrick, 2018). According to O'Boyle et al. (2012), psychopathy trait is associated with impulsivity and criminal aspects and highlighted that psychopathy is strongly related to CWB. Psychopath is also positively associated with workplace bullying (Daderman \& Ragnestal-Impola, 2019) and supervisor expediency (Fayyaz et al., 2020). Psychopaths can harm others, and use various tactics to achieve their goals. They can go to any level to deteriorate people from their goals, and this is possible due to the various qualities found in psychopaths. These qualities include; their social skills and intelligence. They can also harm the other party to pull them away from the task at hand, as Boddy (2006) suggested. Two of the major traits of 
psychopaths include self-centered impulsivity and fearless dominance. These two attributes, if infused together, result in a truly psychopathic personality. Self-centered impulsivity is a major factor that indicates towards zero-concern for deadlines or responsibility, plus a thrill-seeking attitude (Lilienfeld et al., 2005). Psychopathic individuals' activities can lead to an increased level of hostility between the employees and give rise to lobbying within workplace settings. Therefore, by diverting the attention of devoted employees towards other problems, these people can conduct their agendas (Boddy, 2006). Distracting others from work is associated with a type of counterproductive work behavior. Therefore, our research proposes the following hypothesis:

H3: Psychopathy is positively associated with Time Banditry

\section{Islamic Work Ethics as a Moderator}

Islamic ethics differentiate between positive and negative behavior from the Islamic perspective (Beekun, 1997). IWE refers to the code of conduct for employees at the workplace (Mohamed et al., 2010). It is a moral obligation to approach the work-related goals, encourage the good deed, and avoid detrimental practices despite abusive supervision (Ahmad \& Owoyemi, 2012). The theory of planned behavior illustrates that individual beliefs, attitudes, and intention lead to behavior, while individuals have the ability to control behavior (Fishbein \& Ajzen 1975, Fishbein \& Ajzen, 1980). Relying on this theory, the researcher argues that a person who believes in the philosophy of IWE will refrain from involving in unethical practices even in the presence of dark triads because of self-control. Previously IWE has been studied in minimizing the impact of negative antecedents like abusive supervision (Hashmi et al., 2019; Islam et al., 2020; Javed et al., 2019; Khalid et al., 2018). Another study confirmed that IWE interacts with hindrance stressors and reduces its negative impact on job satisfaction (Tufail et al., 2017). Also, the interpersonal conflict with the mediating effect of psychological distress (Qayyum et al., 2018) has been reduced by the IWE. IWE has also been studied as buffering the negative impact of job stress on job satisfaction (Ajmal \& Irfan, 2014). IWE is considered as probable moderator because it has its focus on inhibition from unethical behavior, while its essentials include hard work, commitment, and dedication (Khan et al., 2015). Yousef (2001) stated that adopting IWE would lead to commitment and justice at the workplace. Moderator discussion is grounded on the theory of planned behavior (Ajzen, 1985) that states that beliefs and intentions affect individuals' behavior and discusses an individual's ability of self-control. In the extant research, it is argued that even in the presence of dark triads the individual having belief in Allah and IWE will refrain him/herself from getting involved in expediency.

The presence of IWE also mitigates the harmful effect of the dark triad effect on supervisor expediency (Fayyaz et al., 2020). IWE creates a positive workplace environment and individuals are less likely to involve in deviant behavior and promotes positive outcomes. The high involvement climate has involved the Machiavellianism and Narcissism personalities in the organizational citizenship behavior (Webster \& Smith, 2019). Another study confirmed that workplace spirituality lessens the detrimental effect of Narcissism and Psychopath personalities in bullying behavior (Lata \& Chaudhary, 2020). Therefore, it is also hypothesized that 
IWE will also moderate the relationship between dark triad personalities and time banditry: H4: IWE moderates the impact of Machiavellianism on Time banditry such that the relationship is weaker when the IWE will be high.

H5: IWE moderates the impact of Narcissism on Time banditry such that the relationship is weaker when the IWE will be high.

H6: IWE moderates the impact of Psychopath on Time banditry such that the relationship is weaker when the IWE will be high.

\section{METHODOLOGY}

\section{Participants and Procedures}

This research is explanatory in which questionnaires were utilized for data collection. The target population was the employees working in the Islamic banking sector within Islamabad and Rawalpindi. The study was time-lagged, and therefore, the data collected from employees were at two different time intervals with a 2-weeks gap. The questionnaire has a brief introduction to the research objectives. It was distributed to 300 employees, out of which 230 questionnairs were received and 204 were properly filled.

\section{Measures \\ Dark Triad}

To evaluate Dark Triads, our research utilizes a 27-item measure construct on a 5-point Likert scale. This construct was developed by Paulhus and William(2002) and was formulated to conceptualize the notion of Dark triads. The SD3 scale is said to adequately cover the aspects of Dark triad subdimensions, which includes the three factors of Narcissism, Machiavellianism, and Psychopathy. For this purpose, the standard measures for Dark triads were used within the SD3 scale.

\section{Time Banditry}

The time banditry's construct in our research used a 31-item scale on a 5point Likert scale. The measure construct was developed by Brock, Martin, Buckley in 2013.

\section{Islamic Work Ethics}

The measurement instrument utilized for IWE used 17 items scale by Ali (1992). All scales are measured on a 5-point Likert scale ranging from 1= "Strongly Disagree", and 5= "Strongly Agree".

\section{RESULTS}

For preliminary analysis, the study employed descriptive and correlation analysis, whereas for hypotheses testing, the study employed the hierarchal regression analysis. Table 1 summarizes the result for the descriptive statistics, correlation, and scale reliability. Table 1 confirms that all the scales are reliable as the Cronbach Alpha is greater than 0.7 i.e Machiavellianism (0.89), Narcissism (0.77), Psychopath (0.76), IWE (0.84), and Time Banditry (0.856). The correlation table also provides initial support for the hypotheses. The correlation confirms the positive relation between Machiavellianism and time banditry $(r=-0.327, p<0.01)$. Also, 
there is a positive relation between Narcissism and Time banditry $(r=0.27, p<0.01)$ and positive relation between Psychopath and Time banditry $(r=0.42, p<0.01)$ but there is no significant relationship between IWE and Time banditry $(r=-0.051)$.

TABLE 1

Means, Standard Deviation, Correlations, and Reliabilities

\begin{tabular}{lllllllllll}
\hline \hline & Mean & SD & 1 & 2 & 3 & 4 & 5 & 6 & 7 & 8 \\
\hline 1.Gender & 1.42 & 0.49 & - & & & & & & & \\
2. Age & 2.29 & 1.14 & -0.077 & - & & & & & & \\
3. Education & 2.75 & 0.85 & -0.001 & 0.136 & - & & & & & \\
4. Machiavellianism & 2.74 & 0.75 & 0.087 & -0.03 & -0.069 & -0.89 & & & & \\
5. Narcissism & 2.75 & 0.55 & -0.005 & -0.072 & 0.016 & $.159^{*}$ & -0.774 & & & \\
6. Psychopath & 2.71 & 0.57 & 0.06 & 0.006 & 0.061 & $.503^{* *}$ & $.161^{*}$ & -0.764 & & \\
7. IWE & 4.01 & 0.43 & $-.143^{*}$ & 0.049 & -0.062 & -0.023 & 0.002 & $-.163^{*}$ & -0.841 & \\
8. Time Banditry & 2.84 & 0.51 & 0.04 & -0.065 & 0.005 & $.327^{* *}$ & $.270^{* *}$ & $.417^{* *}$ & -0.051 & -0.856 \\
\hline \hline
\end{tabular}

*. $p$-value $<0.05$ level (2-tailed).

**. $p$-value $<0.01$ level (2-tailed).

TABLE 2

Regression Analysis

\begin{tabular}{|c|c|c|c|c|c|c|}
\hline \multirow[t]{3}{*}{ Variables } & \multirow{2}{*}{\multicolumn{2}{|c|}{$\begin{array}{l}\text { Time banditry } \\
\text { Model } 1\end{array}$}} & \multirow{2}{*}{\multicolumn{2}{|c|}{$\begin{array}{l}\text { Time Banditry } \\
\text { Model } 2\end{array}$}} & \multirow{2}{*}{\multicolumn{2}{|c|}{ Time Banditry }} \\
\hline & & & & & & \\
\hline & $\beta$ & $T$ & $\beta$ & $T$ & $\beta$ & $T$ \\
\hline Control variables & & & & & & \\
\hline Gender & 0.036 & 0.495 & 0.008 & 0.114 & -0.013 & -0.194 \\
\hline Age & -0.029 & -0.895 & -0.022 & -0.758 & -0.029 & -1.049 \\
\hline Education & 0.009 & 0.199 & -0.001 & -0.017 & -0.004 & -0.113 \\
\hline Machiavellianism & & & $.094 \dagger$ & 1.81 & $.980 *$ & 2.203 \\
\hline Narcissism & & & $.179 * *$ & 3.03 & 0.079 & 0.765 \\
\hline Psychopath & & & $.287 * *$ & 4.3 & $.470 * *$ & 4.282 \\
\hline Islamic Work ethics(IWE) & & & 0.008 & 0.109 & $.722 *$ & 2.494 \\
\hline Interactions & & & & & & \\
\hline Machiavellianism x IWE & & & & & $-.217 *$ & -1.99 \\
\hline Narcissism x IWE & & & & & 0.009 & 0.239 \\
\hline Psychopath x IWE & & & & & $-.058 *$ & -2.375 \\
\hline$R^{2}$ & 0.006 & & 0.232 & & 0.284 & \\
\hline$\Delta R^{2}$ & 0.006 & & 0.227 & & 0.052 & \\
\hline
\end{tabular}

The study utilizes hierarchical regression for hypotheses testing. The interaction effect of IWE in the relationship between dark triad and time banditry ( $\mathrm{H} 4, \mathrm{H} 5$, and $\mathrm{H} 6$, respec- 
tively) were examined based on standardized values of the three-step hierarchical regression analysis (Judd et al., 2001).

Initially, using hierarchical regression, age, gender and education were entered as control variables at the first step. In the second step, the Dark Triad i.e., Machiavellianism, Narcissism, Psychopath, and IWE were entered. In the final step, Machiavellianism x IWE, Narcissism x IWE, Psychopath x IWE, three interaction terms were selected to examine their impact on Time banditry. Table 2 presents the results. The results showed that the dark triad was positively associated with Time banditry. Table 2 shows that there is a positive impact of Machiavellianism $(\beta=0.094, p<0.1)$ Narcissism $(\beta=0.179, p<0.1)$ and Psychopath $(\beta=$ $0.287, p<0.1)$ on the time banditry which confirm H1, $\mathrm{H} 2$ and $\mathrm{H} 3$. The result also highlights that psychopath personalities are most likely to indulge in time banditry.

Table 2 also shows the negative interaction between Machiavellianism and IWE ( $\beta=$ $-0.217, p<0.05)$, which accepts H4. Also, the IWE weakens the impact of Psychopath on time banditry $(\beta=-0.058, p<0.05)$ which accepts $\mathrm{H} 6$ whereas there is no interaction effect of Narcissism and IWE which rejects H5.

\section{Discussion}

Few studies have focused on the mitigation of the detrimental effect of Dark triad personalities in the workplace environment. This research investigated the organizational factor i.e. Islamic work ethics, which can attenuate the dark triad and time banditry relationship. The study confirms that Machiavellianism, Narcissism, and Psychopath have an impact on the time banditry i.e. H1, H2, and H3. The findings are in line with the previous studies (Fayyaz et al., 2000), confirming that Narcissism and psychopath will contribute to counterproductive work behavior. Additionally, this study's findings also confirm the result focused on the undesirable behavior, i.e., cyberloafing (Lowe-Calverley \& Grieve, 2017) and cutting corners (Jonason \& O'Connor, 2017) which is undesirable behavior. Our study results are aligned with a previous study that mentioned that the Dark triad impacts cyberloafing (Lowe-Calverley \& Grieve, 2017).

From the perspective of Islamic work ethics, this research confirms that IWE weakens the relationship between Machiavellianism and Time banditry. This result confirmed that the Mach individual with high IWE would involve lesser in the time banditry as shown in Figure 1, whereas Mach with Low IWE will be doing time banditry at the workplace. The findings are also consistent with the previous study that Machiavellianism behavior was weakened by the IWE (Fayyaz et al., 2020). The results are also in line with the previous study (Daderman \& Ragnestal-Impola, 2019), which mentioned that Honesty-Humility moderates the association between Machiavellianism and the use of bullying tactics. This research also confirmed that the IWE will also weaken the relationship between the psychopath and Time banditry at the workplace as shown in figure 2. This finding also supports the previous literature on counterproductive work behavior. 


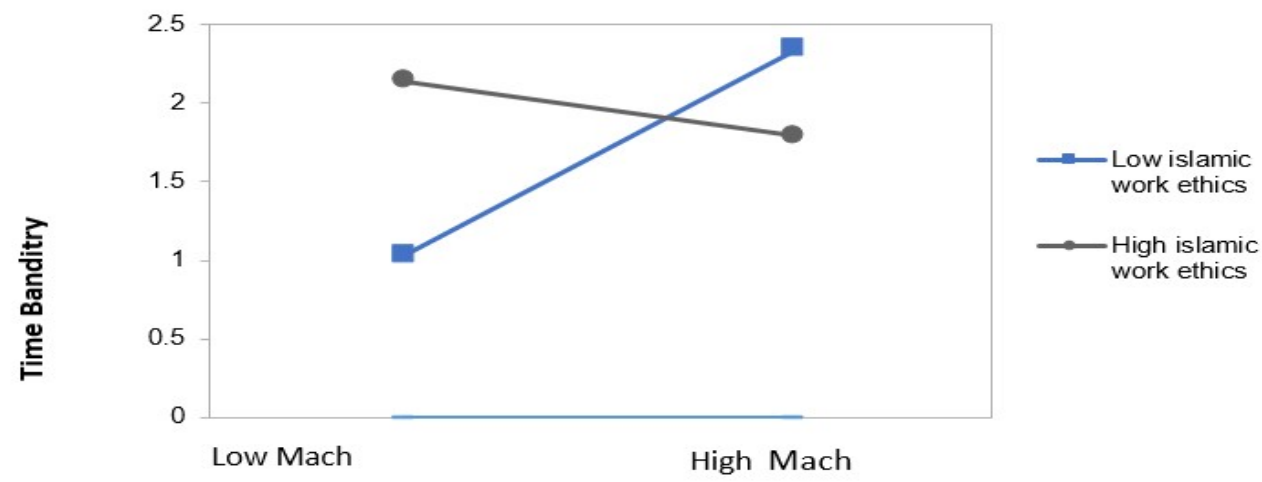

FIGURE 1. Moderation of IWE on machiavellianism and time banditry relationship

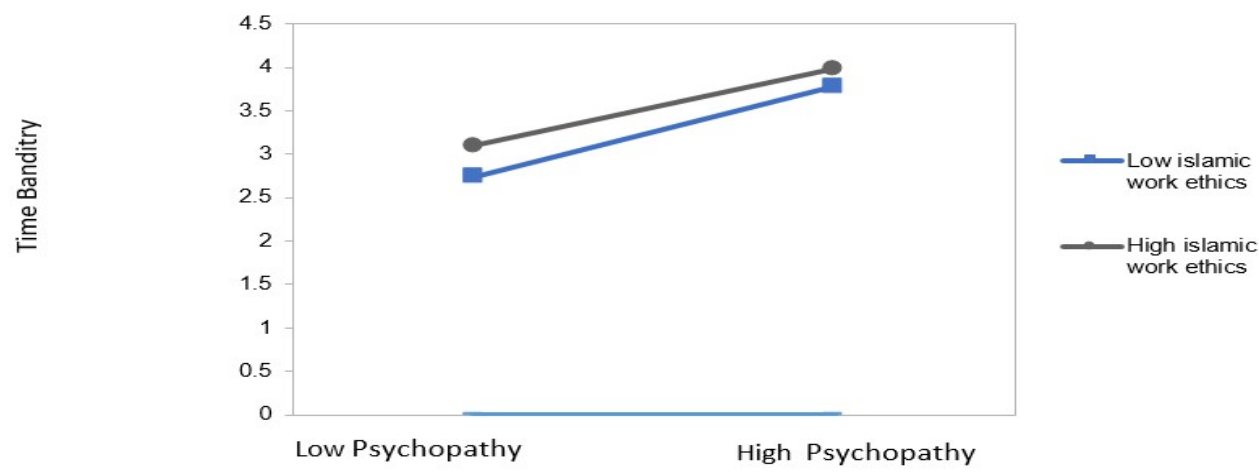

FIGURE 2. Moderation of IWE on psychopath and time banditry relationship

\section{Conclusion}

A substantial amount of literature exists on Dark Triad and Counterproductive work Behavior. However, the present study addresses the research gap by investigating the Dark Triad's impact on Time Banditry. Further, the study analyses the impact of IWE as a moderator on the relationship between the Dark Triad and Time Banditry. The results provide evidence that the Dark triad has an impact on Time Banditry. The result also contributes to the literature that IWE can help combat the issue of Time Banidtry associated with the Dark Triad in the Banking Sector. IWE creates a positive work environment, and it was emphasized that an individual, even with the presence of dark triads, would refrain from involving in unethical behavior i.e., expediency.

\section{Implications}

Time banditry is a fundamental issue, which is draining out the key resources of an organization. The current study has several implications for the managers regarding time banditry. This study apprises managers that IWE can alleviate the employees with Dark Triad personalities from practicing undesirable behavior i.e., Time Banditry. IWE plays a critical role and provides managers with practice when confronted with the challenge to manage the Dark Triad employees. Indeed, Islamic work ethics is a basic value used to improve both employee and organizational performance. Though previous studies have highlighted the moderating 
role of IWE, which buffers the effect of negative outcome due to negative antecedents like abusive supervision (Hashmi et al., 2019; Islam et al., 2020; Javed et al., 2019; Khalid et al., 2018), interpersonal conflict (Qayyum et al., 2018), hindrance and challenge stressor (Tufail et al., 2017). Thus, organizations encourage their managers towards IWE practices. The study also draws attention to the personality and their negative outcome at the workplace. The study confirms that all three personalities i.e. Machiavellianism, Narcissism, and Psychopath will participate in the time banditry behavior in which psychopaths are the most prone to the negative outcome. Therefore, managers should closely monitor their subordinates who possess these personality traits, and are more prone to time banditry behavior, and managers can intercept this behavior with ethical practices. As a moral champion, the Manager practices the IWE and can promote this code of conduct at the workplace (Khan et al., 2015). Proactive managers can also cautious at the hiring stage that individuals recruited must not scoring high on the dark triad.

\section{Limitations and Directions for Future Research}

Few limitations of the study need to be acknowledged. Firstly, dark personality was selfreported which can be improved by asking from other sources. Previous studies have validated the scale and used the Dark triad in their research (Smith et al., 2016).

Secondly, the study has utilized a single moderator in the study whereas, several other contextual moderators can affect the time banditry behavior. Future researches can explore the ignored contextual moderators.

Thirdly, the target sample was collected from the banking sector, i.e., Both public and private banks operating in Pakistan, whereas future research can focus on other sectors i.e., hospitality, education, health. Also, multinational organizations can be targeted by having diverse cultures.

\section{REFERENCES}

Ajzen, I. (1985). From intentions to actions: A theory of planned behavior. In Action control (pp. 11-39). Springer, Berlin, Heidelberg. doi: https://doi.org/10.1007/978-3-642-69746-3_2

Ali, A. J., \& Al-Owaihan, A. (2008). Islamic work ethic: A critical review. Cross Cultural Management: An international Journal, 15(1), 5-19. doi: https://doi.org/10.1108/13527600810848791

Beekun, R. I., \& Badawi, J. A. (2005). Balancing ethical responsibility among multiple organizational stakeholders: The Islamic perspective. Journal of Business Ethics, 60(2), 131-145. doi: https://doi.org/10.1007/s10551-004-8204-5

Bennett, R. J., \& Robinson, S. L. (2000). Development of a measure of workplace deviance. Journal of Applied Psychology, 85(3), 349-360. doi: https://doi.org/10.1037/0021-9010.85.3.349

Boddy, C. R. (2006). The dark side of management decisions: Organisational psychopaths. Management Decision, 44(10), 1461-1475. doi: https://doi.org/10.1108/00251740610715759 
Brock Baskin, M. E., \& McKee, V. (2019). Employee perceptions of climate as an antecedent of time banditry in the workplace. International Journal of Selection and Assessment, 27(1), 83-89. doi: https://doi.org/10.1111/ijsa.12236

Brock Baskin, M. E., McKee, V., \& Buckley, M. R. (2017). Time banditry and impression management behavior: Prediction and profiling of time bandit types. Journal of Leadership $\mathcal{E}$ Organizational Studies, 24(1), 39-54.

doi: https://doi.org/10.1177/1548051816661479

Brock, M. E., Martin, L. E., \& Buckley, M. R. (2013). Time theft in organizations: The development of the time banditry questionnaire. International Journal of Selection and Assessment, 21(3), 309-321. doi: https://doi.org/10.1111/ijsa.12040

Bushman, B. J., \& Baumeister, R. F. (1998). Threatened egotism, narcissism, self-esteem, and direct and displaced aggression: Does self-love or self-hate lead to violence?. Journal of Personality and Social Psychology, 75(1), 219-229.

doi: https://doi.org/10.1037/0022-3514.75.1.219

Campbell, W. K., Foster, C. A., \& Finkel, E. J. (2002). Does self-love lead to love for others? A story of narcissistic game playing. Journal of Personality and Social Psychology, 83(2), 340. doi: https://doi.org/10.1037/0022-3514.83.2.340

Christie, R., \& Geis, F. (1970). Scale construction. Studies in Machiavellianism, 34(4), 10-34. doi: https://doi.org/10.1016/B978-0-12-174450-2.50007-5

Daderman, A. M., \& Ragnestal-Impola, C. (2019). Workplace bullies, not their victims, score high on the Dark Triad and Extraversion, and low on Agreeableness and HonestyHumility. Heliyon, 5(10), e02609. doi: https://doi.org/10.1016/j.heliyon.2019.e02609

Dahling, J. J., Whitaker, B. G., \& Levy, P. E. (2009). The development and validation of a new Machiavellianism scale. Journal of Management, 35(2), 219-257.

doi: https://doi.org/10.1177/0149206308318618

Fayyaz, H., Gulzar, A., \& Abbass, N. (2020). When dark triad personality leads to supervisors expediency: An Islamic work perspective. Journal of Islamic Business and Management, 10(1), 204-221. doi: https://doi.org/10.26501/jibm/2020.1001-015

Fishbein, M., \& Ajzen, I. (1975). Belief, attitude, intention and behavior: An introduction to theory and research. Addison Wisley.

Fishbein, M., \& Ajzen, I. (1980). Predicting and understanding consumer behavior: Attitudebehavior correspondence. In I. Ajzen, \& M. Fishbein (Eds.), Understanding attitudes and predicting social behavior (pp. 148-172). Prentice-Hall.

Ford, C. V., King, B. H., \& Hollender, M. H. (1988). Lies and liars: Psychiatric aspects of prevarication. The American Journal of Psychiatry, 145, 554-562. doi: https://doi.org/10.1176/ajp.145.5.554

Giammarco, E. A., Atkinson, B., Baughman, H. M., Veselka, L., \& Vernon, P. A. (2013). The relation between antisocial personality and the perceived ability to deceive. Personality and Individual Differences, 54, 246-250. doi: https://doi.org/10.1016/j.paid.2012.09.004 Grijalva, E., \& Newman, D.A. (2015). Narcissism and counterproductive work behavior (CWB): Meta-analysis and consideration of collectivist culture, big five personality, and narcissism's facet structure. Applied Psychology: An International Review, 64, 93-126. doi: https://doi.org/10.1111/apps.12025 
Harms, P., Spain, S., \& Hannah, S. (2011). Leader development and the dark side of personality. The Leadership Quarterly, 22, 495-509.

doi: https://doi.org/10.1016/j.leaqua.2011.04.007

Hashmi, S. D., Khan, K., Ullah, I., Gulzar, S., \& Haider, A. (2019). Religion can change intentions: Interactive effect of abusive supervision and Islamic work ethics on workplace gossip. Journal of Islamic Business and Management, 9(1), 160-175.

Henle, C. A., Reeve, C. L., \& Pitts, V. E. (2010). Stealing time at work: Attitudes, social pressure, and perceived control as predictors of time theft. Journal of Business Ethics, 94(1), 53-67. doi: https://doi.org/10.1007/s10551-009-0249-z

Islam, T., Ahmad, S., Kaleem, A., \& Mahmood, K. (2020). Abusive supervision and knowledge sharing: moderating roles of Islamic work ethic and learning goal orientation. Management Decision, 59(2), 205-222. doi: https://doi.org/10.1108/MD-08-2019-1069

Javed, B., Fatima, T., Yasin, R. M., Jahanzeb, S., \& Rawwas, M. Y. (2019). Impact of abusive supervision on deviant work behavior: The role of Islamic work ethic. Business Ethics: A European Review, 28(2), 221-233. doi: https://doi.org/10.1111/beer.12212

Jia, H., Jia, R., \& Karau, S. (2013). Cyberloafing and personality: The impact of the big five traits and workplace situational factors. Journal of Leadership and Organizational Studies, 20, 358-365. doi: https://doi.org/10.1177/1548051813488208

Jonason, P. K., \& O'Connor, P. J. (2017). Cutting corners at work: An individual differences perspective. Personality and Individual Differences, 107, 146-153.

doi: https://doi.org/10.1016/j.paid.2016.11.045

Jones, D. N., \& Paulhus, D. L. (2010). Different provocations trigger aggression in narcissists and psychopaths. Social Psychological and Personality Science, 1(1), 12-18. doi: https://doi.org/10.1177/1948550609347591

Khalid, M., Bashir, S., Khan, A. K., \& Abbas, N. (2018). When and how abusive supervision leads to knowledge hiding behaviors. Leadership E Organization Development Journal, 39(6), 794-806. doi: https://doi.org/10.1108/LODJ-05-2017-0140

Khan, K., Abbas, M., Gul, A., \& Raja, U. (2015). Organizational justice and job outcomes: Moderating role of Islamic work ethic. Journal of Business Ethics, 126(2), 235-246. doi: https://doi.org/10.1007/s10551-013-1937-2

Kish-Gephart, J. J., Harrison, D. A.,\& Trevino, L. K. (2010). Bad apples, bad cases, and bad barrels: Meta-analytic evidence about sources of unethical decisions at work. Journal of applied psychology, 95(1), 1-31. doi: https://doi.org/10.1037/a0017103

Lata, M., \& Chaudhary, R. (2020). Dark Triad and instigated incivility: The moderating role of workplace spirituality. Personality and Individual Differences, 166, 110090. doi: https://doi.org/10.1016/j.paid.2020.110090

Lilienfeld, S. O., Widows, M. R., \& Staff, P. A. R. (2005). Psychopathic personality inventoryTM-revised. Social Influence (SOI), 61(65), 1-6.

Lowe-Calverley, E., \& Grieve, R. (2017). Web of deceit: Relationships between the dark triad, perceived ability to deceive and cyberloafing. Cyberpsychology: Journal of Psychosocial Research on Cyberspace, 11(2), 1-12. 
Martin, L. E., Brock, M. E., Buckley, M. R., \& Ketchen, D. J. (2010). Time banditry: Examining the purloining of time in organizations. Human Resource Management Review, 20(1), 26-34. doi: https://doi.org/10.1016/j.hrmr.2009.03.013

Mohamed, N., Karim, N. S. A., \& Hussein, R. (2010). Linking Islamic work ethic to computer use ethics, job satisfaction and organisational commitment in Malaysia. Journal of Law and Governance, 5(1), 13-23.

Murtaza, G., Abbas, M., Raja, U., Roques, O., Khalid, A., \& Mushtaq, R. (2016). Impact of Islamic work ethics on organizational citizenship behaviors and knowledge-sharing behaviors. Journal of Business Ethics, 133(2), 325-333.

doi: https://doi.org/10.1007/s10551-014-2396-0

O’Boyle, E. H., Forsyth, D. R., Banks, G. C., \& McDaniel, M. A. (2012). A meta- analysis or the dark triad and work behaviour: A social exchange perspective. Journal of Applied Psychology, 97, 557-579. doi: https://doi.org/10.1037/a0025679

Palmer, J. C., Komarraju, M., Carter, M. Z., \& Karau, S. J. (2017). Angel on one shoulder: Can perceived organizational support moderate the relationship between the Dark Triad traits and counterproductive work behavior?. Personality and Individual Differences, 110, 31-37. doi: https://doi.org/10.1016/j.paid.2017.01.018

Paulhus, D. L., \& Williams, K. M. (2002). The dark triad of personality: Narcissism, Machiavellianism, and psychopathy. Journal of Research in Personality, 36, 556-563. doi: https://doi.org/10.1016/S0092-6566(02)00505-6

Qayyum, A., Kousar, S., Jamil, R. A., \& Sarmad, M. (2018). Relationship between workfamily and interpersonal conflicts: Mediating role of psychological distress and the moderating effect of Islamic work ethics. Journal of Islamic Business and Management, 8(2), 501-519. doi: https://doi.org/10.26501/jibm/2018.0802-010

Raskin, R., \& Terry, H. (1988). A principal-components analysis of the narcissistic personality inventory and further evidence of its construct validity. Journal of Personality and Social Psychology, 54, 890-902. doi: https://doi.org/10.1037/0022-3514.54.5.890

Schneider, T. J., \& Goffin, R. D. (2012). Perceived ability to deceive and incremental prediction in pre-employment personality testing. Personality and Individual Differences, 52(7), 806-811. doi: https://doi.org/10.1016/j.paid.2012.01.015

Tufail, M., Shahzad, K., Gul, A., \& Khan, K.(2017). The Impact of Challenge and Hindrance Stressors on Job Satisfaction: Moderating Role of Islamic Work Ethics. Journal of slamic Business and Management, 7(1), 100-113.

doi: https://doi.org/10.26501/jibm/2017.0701-008

Webster, B. D., \& Smith, M. B. (2019). The dark triad and organizational citizenship behaviors: The moderating role of high involvement management climate. Journal of Business and Psychology, 34(5), 621-635.

doi: https://doi.org/10.1007/s10869-018-9562-9 